Paper published as Breen-Smyth M (2012). An interview with George Giacaman. Critical Studies on Terrorism 5(1):139-145

\title{
Interview with George Giacaman
}

\section{Marie Breen-Smyth, University of Surrey}

Marie Breen-Smyth interviews George Giacaman, the Co-Founder and Director of Muwatin, The Palestinian Institute for the Study of Democracy. George is a prominent commentator on public affairs in the Palestinian and Arab press, is a regular commentator for BBC TV and World Service Radio and has authored a number of key works including his most recent book "Before and After Arafat: Political Transformation during the Second Intifada" (2011, in Arabic). He is editor of On the Democratic Option, and Co-editor of After Oslo, and State Formation in Palestine, and has published extensively in both English and Arabic. His areas of interest include democratization, the role and function of civil society, Palestinian political development, Islamic philosophy, contemporary philosophical and intellectual trends. George is co-founder of the the MA Program in Democracy and Human Rights in the Department of Philosophy and Cultural Studies at Birzeit University. He has also served as Dean of Graduate Studies, Dean of the Faculty of Arts, and Chair of the Department of Philosophy and Cultural Studies at Birzeit. He holds a Ph.D in Philosophy from The State University of New York at Buffalo, where he also taught for three years before moving to Birzeit.

\section{Marie Breen-Smyth: What now are the key factors or drivers in Palestinian politics that determine the possibility of progress towards a settlement?}

George Giacaman: The PLO began a gradual process of inching towards the two state solution since the mid 1970's, but became formally part of its political program in 1988 during the meeting of the Palestinian National council (the PLO's "parliament") in Algiers where the principle of the division of Palestine was accepted. Since then, the PLO pursued a settlement based on this but was faced with Israeli rejectionism. It took former US Secretary of State James Baker multiple visits to the region and intensive pressure on the then government of Israel to agree to take part in the Madrid Conference which took place in late 1991. This was followed by the Oslo accords, the first of which was signed in 1993 and involved the recognition by the PLO of the State of Israel, while Israel recognized the PLO as a representative of Palestinians, but did not recognize their right to self-determination, let alone that they have a right to a state.

This has been the trajectory of the PLO since, to seek a settlement along these lines. Even Hamas has accepted the two-state solution during the past few years as can be amply documented, even if with the qualifier that they, that is Hamas, will not recognize Israel. But no one asked right-wing Israeli parties, including those now in government, to 
recognize the Palestinian's right to a state, which indeed they do not.

Palestinian politics do not influence progress towards a settlement to any significant degree, but other factors do, including the position of the US on issues. The US has opted to be supportive of various Israeli governments, no matter how extreme, largely because of the influence of the Israel lobby on Congress and the various administrations. In the case of the Obama Administration, this is patently clear: Netanyahu, so to speak, beat Obama on his home ground. The US is hostage to Israel as far as the conflict is concerned. A sorry and pitiful sight indeed for a great power and to the detriment of Israel and the US, something which many Israelis also believe.

\section{MBS: What, in your view are the implications of the Arab revolutions for progressing the cause of Palestine?}

GG: The Arab uprisings or revolutions as they are referred to in Egypt, are still in a state of flux. Egypt will lead the way and is bound to become a model. Counter-revolutionary forces, both internal and external, are now at work including some sponsored by Arab regimes in alliance with the US. The crux of the matter is the degree of democratization that transpires after elections in Egypt, Tunisia, and other countries, and the extent to which public opinion is reflected in domestic and foreign policies, including in relation to Israel and Palestine. To the degree that this takes place, this will be advantageous to Palestinians since Arab public opinion has always been known to be supportive of the Palestinian cause, but the authoritarian regimes in the Arab world that are under the hegemony of the US made sure that this popular sentiment did not affect their policies. Egypt under Mubarak, is obviously a clear case in point, but also are several other Arab countries where this applies.

After the elections of new parliaments in Egypt, Tunisia and other countries, and if elections are not rigged, one should expect that there will be demands for change of policies on the part of the newly elected parliaments. On the whole, therefore, the prospects appear propitious from a Palestinian perspective, but it will take some time for the US to begin changing its policies in the region, specifically in relation to the conflict in Palestine. But there is a good chance that such a change will take place in the medium term.

\section{MBS: How do you regard the Palestinian Authority's campaign at the United Nations for Palestinian statehood?}

GG: After twenty years of negotiations since the Madrid Conference in late 1991, the PA does not have another twenty years for further negotiations while Israel continues building illegal settlements that undermine any possible peace agreement - except one completely on its own terms. This situation has led to the loss of credibility and indeed raised questions about the legitimacy of the continued existence of the PA. For 
Palestinians never envisioned that the PA should exist permanently as a large municipality to administer the affairs of Palestinians, under Israeli sovereignty. With the deadlock in political negotiations after Obama gave in to internal pressure by the various Israel lobbies, including a majority in Congress who act as lobbyists for a foreign government, the PA reached a point of crisis. The move for statehood at the UN was meant to begin a process of partial extrication of the conflict from the straight jacket of bilateral negotiations that had led to nowhere. It was meant to generate a diplomatic crisis, in part, in the hope that it will prod the US and major European countries into a different kind of involvement by declaring a clear position on the frame of reference for any future negotiations. This aspired to halt the expansion of illegal settlements and to confirm that the 1967 lines are the starting point of negotiations.

This was a bold gamble on the part of the PA because it brings it into conflict with the US, given the US aversion to the use of its veto power in the Security Council. This is especially acute, given the changing political scene in several Arab countries, where public opinion is likely to be more vociferous in opposition to US support for Israel. As of the end of December 2011, the application for recognition is still under discussion by the various committees of the Security Council. It also appears that the US has succeeded in convincing several members of the Security Council not to give a positive response for the application. Since nine members positive response are needed for the application to go for a vote, the US may have succeeded in averting a veto.

The main issue here, however, is what next. Will the PA submit an application to the General Assembly for recognition? Will the PA follow up with further diplomatic moves if negotiations remain stalled, or not? Further moves of a political or legal nature, such as pursuing the Goldstone report in the relevant UN bodies to which it will be entitled after joining them once it has observer status, will put it in direct conflict with Israel and the US, even more so than the bid for recognition. It remains to be seen if the PA has the political will to take such a course, but its options are limited and it cannot continue to tolerate the present status quo since ultimately, it will lose control of the "street" and with it whatever internal legitimacy it has left.

\section{MBS: What is the likely outcome in terms of Israel's status with the international community?}

GG: Israel is experiencing a state of relative political isolation which will continue to increase if the political process remains stalled. This is the combined view of all Israeli security services as was reported in the Hebrew press on the eve of the PA's bid at the UN. However, it will take more concrete damage to the State of Israel to make the present government take an initiative, since this is a government that has opted so far for political paralysis given its composition as a coalition with extreme right wing parties, more interested in land usurpation from Palestinians than peace A reshuffle of the cabinet and inclusion of other parties is not impossible at one point, but for whatever reason, Netanyahu has not yet decided that this is the most opportune moment, 
especially since the inclusion of other parties, such as Kadima, will entail a political price of the type demanded in earlier negotiations before the formation of the present government, such as rotation on the position of prime minister, which he did not accept.

\section{MBS: How do you assess the prospects for re-starting a peace process in the region?}

GG: Since the Madrid Conference in late 1991, there has been twenty years of "negotiations". The phrase "peace process" has become a stale and decrepit euphemism for "conflict management", meaning not resolution of the conflict but preventing it from exacerbation and under "control." After twenty years, the "peace process" has run its course and came to an end as an on-going process with no definite end in sight. Any revival of such a process will have to be on very different terms. All concerned know this, but the US and the EU and the Quartet are still trying to revive a dead process because they have no leverage with the State of Israel, meaning to play a clearly assertive role that puts clear pressure on the Israeli government to pursue a settlement, even while they continue to claim that the outlines of a settlement are clearly known.

Public opinion in the US and more so in Europe is supportive of the two-state solution and the recognition of Palestine as a state. This is not reflected in governmental policies. So much for "democracies".

\section{MBS: In the light of US foreign policy towards the Middle East and Israel since the election of Obama, can you be optimistic the prospects for ending the occupation?}

GG: Given the record of the Obama Administration so far, there is no reason to be optimistic. The Palestinian Authority (PA), but not necessarily Palestinians, may be hoping that if Obama wins a second term, he might be more assertive in relation to any one Israeli government. But there is no evidence for this, and it could be viewed as "hope against hope". What Palestinians need to do is to use whatever sources of strength they have and, hopefully, be empowered by the changing scene in Arab Countries. This will be a crucial factor in the medium and long term.

\section{MBS: How do you see current and future trends in Israeli settlement building?}

GG: The settlement process and illegal land appropriation from Palestinians continue, and there is no reason to expect that they will stop as long as there are no sanctions for such an endeavor. This has been the case since 1967 when Israel occupied Palestinian land, in this case, the West bank and Gaza, and was actually exacerbated during the Oslo process, and continues apace now. There is no peace strategy for Israel especially with the government under Netanyahu, and from the perspective of many Israelis as well, this appears to be to the detriment of the state of Israel as this will ensure that it will have to live indefinitely by the sword. A very sorry and tragic prospect indeed, and Palestinians will pay the heavier price, and the conflict will continue to radicalize the Arab region, especially if some degree of democratization is ushered in. 
The present course appears to be sheer lunacy for all concerned, including many sane Israelis. And if a majority in the US Congress think they are helping Israel by rubberstamping any policy any Israeli government pursues, they are in reality pursuing an antiIsraeli policy if by that is meant Israel not perpetually being at war, hot or cold, with the region surrounding it, not only with Palestinians. This will become clearer in the coming months and years.

MBS: What is the role of politics versus armed resistance in the Palestinian struggle? Our journal operates in the field of so called 'terrorism studies' - can the term 'terrorism' be usefully applied to the Palestinian and Israeli contexts? Is Hamas' designation as a terrorist organisation a help or a hindrance to the peace process? What effects does it generate and what can be done to work around this obstacle?

GG: Both politics and armed resistance have been pursued by Palestinians. Both have failed in achieving the aims of the PLO, which is to establish a sovereign state within the 1967 lines. The reason for this is obvious: Palestinians are no match for Israel in terms of political and military power. Without Arab support of various kinds they will not achieve their aims. After the Arab uprisings the scene is bound to change, even if the degree is yet not known. Analysts in Israel and the US are well aware of this and their governments are trying their best to contain the change in so far as possible. But it is clear that increased support for the Palestinians by Arab regimes, at least at the diplomatic level, will be a feature of the new order in Arab countries as a result of the uprisings. The degree of support will depend on the degree of democratization.

Now, as for the word "terrorism", there are varied politically inspired definitions, such as the one the US politicians use, which is not only tendentious but also morally unjustifiable. It is unjustifiable in that it equates, more or less, armed resistance to the US in its Middle Eastern wars, and Israeli wars, with terrorism, if it also involves attacks on civilians. Such attacks are used to lump together different categories of those targeted, both civilian and military, while at the same time absolving states, such as the US and Israel from similar perpetrated acts which also involve targeting civilians.

What is generally agreed upon as a core definition of terrorism, is targeting civilians as prohibited by the Fourth Geneva Convention. But Israel is obviously guilty of this. The list is long, but suffice it to mention the invasion of Lebanon in 1982 which resulted in the death of nearly 20 thousand, mostly civilians, the Israeli invasion of Lebanon in 2006 where the majority of those killed or injured were civilians, and the invasion of Gaza in 2007 with approximately 1400 killed, mostly civilians. And the list can start earlier and go on.

The question is this: What Is terrorism ? If it means targeting civilians, then Israel is equally guilty of the charge, and more so in terms of numbers. If it is argued that Israel did not intend to attack civilians while Palestinians did, the question revolves around 
what intent is. It should be obvious that intent is not established by a psychological test. From the point of view of law, intent is established if the results of the action can be foreseen. In the case of the war on Gaza and in other wars, the results were foreseen and this can be amply documented from Israeli sources as well.

The main issue here is one of double standards. If Palestinians target civilians it is terrorism, while if Israel does, it is not. This is a morally obtuse position, and even worse, it is downright moral cynicism. I repeat, the central issue here is one of double standards and therefore not morally defensible.

\section{MBS: What is the proper role of the international community in resolving the situation of Palestine?}

GG: The "international community" is a euphemism for the Security Council and major European countries and of the balance of power within the world today. With veto power for permanent members of the Security Council, the US as a leading member of the "international community" used its veto over 40 times to protect Israel from condemnation. The EU and major European countries have so far played "second fiddle" to the US and have not pursued an independent policy. What is very ironic in this context, is that major European countries have been content to support the Palestinian authority (PA) financially, thus relieving Israel of its financial obligations as an occupying power (at least after the Israeli re-occupation of the West Bank in 2002), but at the same time, to invert the American saying, they paid the piper but did not call the tune.

If this remains the case, then the US will continue to call the shots, and the "international community" will follow in its wake. The proper role, what ought to be done, however, is that pressure should be brought on the State of Israel to make peace with Palestinians along lines that most European countries maintain they are already known, and indeed also by many former US politician, ambassadors, officials, and Presidential advisers.

\section{MBS: What is your attitude to the two state solution?}

GG: In spite of the fact that during the past two years many commentators, including Palestinians, advocated the one-state solution, on the assumption that the two-state solution is very nearly dead, Palestinian public opinion in the West Bank and Gaza is still in support of it by a clear majority as appears in the most recent opinion polls. In my opinion, the reason for this is that most Palestinians are pragmatic and can see that if the two-state solution appears far off, the other options are even less realistic in the near future.

One should also add that all political parties within the PLO, in addition to Hamas, still advocate, or accept the two-state solution. The reason for this is clear given that this is the solution accepted internationally, including by the US and the EU, for the conflict. Its 
political marketability is the reason, aside from whether it is achievable and possible. In my view it is achievable, but it requires a considerable amount of pressure on Israel for it to be realized, mainly by the US and major European countries, as well as Arab countries. So far, the political will is not there. But given the uprisings in the Arab World, any degree of democratization in Egypt and other countries, will bring about a strategic shift in the relation with the US. From a longer term perspective, the US cannot secure its interests in the region while maintaining its present unquestioning support of Israel's illegal occupation of Palestinian land. Many American observers see this clearly but it is yet to influence policy and politicians.

The same applies in Israel. What has taken place during the last few decades is that the State of Israel has succeeded far too well, in neutralizing any possible outside pressure principally in the US, thanks largely to the influence various Israel lobbies on Congress and within the Administration. As a result, the conflict has been transposed into the domestic Israeli political arena, where the interests of politicians and parties are local, electoral, careerist, and short term. But once the conflict has entered this dark tunnel of Israeli politics, it will not emerge from there without outside pressure. This is where things are at present. And I would add, this is to the detriment of the future of the State of Israel in the region, as many sane Israelis also believe. But it is precisely this success of the State of Israel in warding off any possible external pressure, that is one main reason for the electoral drift towards the extreme right wing in Israel. With such "friends" in the US Congress, Israel does not need any enemies.

\section{MBS: How do you see the respective roles of the Palestinian Authority, the PLO, Fatah and Hamas in Palestinian politics? What are the prospects for reconciliation between Fatah and Hamas?}

GG: There were several attempts at reconciliation between Fatah and Hamas, including the last agreement signed under Egyptian prodding in May 2011. The agreement is yet to be put into effect, and will not be in the near future as this will require both sides to abandon their present alliances. The PA has not been willing so far to part ways with the US, and Hamas will not abandon its regional alliances in the absence of a settlement to the conflict where its role and standing are clear. I expect that reconciliation will take place under two conditions: if a Palestinian state is established, then there will be serious negotiation between Hamas and Fatah about the place of Hamas in the State. And if the political process remains deadlocked, at some point some factions within Fatah will revert to some form of resistance program, at which point both will be able to reconcile some of their differences.

At present, we are in an interim period, and the effort of the PA to go to the UN is in part an attempt to fill the political vacuum that has resulted because of the breakdown of the political process. Again, this is an interim period, even if it lasts for a few years. But it is also a dangerous period given the political vacuum which in the past has been filled by conflict. I think everyone concerned understands this, but a state of paralysis 
grips the major actors, principally because of the hold Israel has over US policy in relation to the conflict. The new factor is the uprisings in several Arab countries which can have a strategic influence, even if in stages, but it is not possible at present to tell in detail the degree of change they will usher in.

\section{MBS: How do you assess the leadership of Mahmoud Abbas, and the challenges for any successor?}

GG: Mahmoud Abbas has pursued a course based on negotiations and was against the "militarization" of the second Intifada as he called it. He was almost completely neglected by Israel after his elections in January 2005, until Hamas gained a majority in PLC elections in January 2006. Thereafter, he continued to follow the same course until the "Annapolis process", the negotiations that began in early 2008 and ended in failure at the end of the same year. Then, two years into the Obama Administration, it became clear to him that no process will be afoot with the extreme right wing government in Israel, given the capitulation of President Obama in the face of internal domestic pressures. Hence, the decision to go the UN was his first bold move, born in desperation rather than hope. But it also required leadership and courage as it was the first move that put him to some degree in conflict with the US and Israel. Whether he will follow it with other bold moves is an open question.

In the absence of a credible political process, any successor to Abbas will face the same daunting challenges. And it will take a very brave fellow indeed who would want to swim close to the rocky and jagged reef that ruptured Abbas' hopes asunder.

George Giacaman and Marie Breen-Smyth met in Birzeit and Ramallah in September and December 2011. 